\title{
Thermal and Mechanical Studies of Biofiller/Poly-3-Hydroxybutyrate Biocomposites
}

\author{
Evgeniy G. Kiselev*a, \\ Andrew P. Kuzmin a and Ivan V. Nemtsev ${ }^{\mathrm{b}}$ \\ ${ }^{a}$ Siberian Federal University \\ 79 Svobodny, Krasnoyarsk, 660041, Russia \\ ${ }^{b}$ Federal Research Center "Krasnoyarsk Science Center SB RAS" \\ 43/50 Akademgorodok, Krasnoyarsk, 660036, Russia
}

Received 18.02.2019, received in revised form 28.04.2019, accepted 11.05.2019

Biodegradable poly-3-hydroxybutyrate $[P(3 H B)]$ and birch wood flour (as filler) were used to prepare powdered blends and then pellets and granules. Pellets were produced by cold pressing of polymer and filler powders; granules were produced from the powders wetted with ethanol. The properties of the initial $P(3 H B)$ and filler and the blends thereof were studied using IR spectroscopy, differential scanning calorimetry, X-ray analysis, and electron microscopy. No chemical bonds between the components were revealed; the blends were physical mixtures. The degree of crystallinity of the blends was lower than that of the initial polymer, suggesting different crystallization kinetics of the blends. The introduction of increasing amounts of filler into the polymer progressively decreased the mechanical strength of the pellets, as confirmed by a decrease in Young's modulus. The resulting composite, based on biodegradable polymers and wood flour, is a promising nontoxic material for the production of wood-based panels for the construction industry and the manufacture of furniture in place of materials produced using toxic polyester resins.

Keywords: $P(3 H B)$, wood flour, fillers, polymer blends, physicochemical properties.

Citation: Kiselev E.G., Kuzmin A.P., Nemtsev I.V. Thermal and mechanical studies of biofiller/poly-3-hydroxybutyrate biocomposites. J. Sib. Fed. Univ. Biol., 2019, 12(3), 302-310. DOI: 10.17516/1997-1389-0304.

(C) Siberian Federal University. All rights reserved

This work is licensed under a Creative Commons Attribution-NonCommercial 4.0 International License (CC BY-NC 4.0).

* Corresponding author E-mail address: evgeniygek@gmail.com

ORCID: 0000-0003-4472-7087 (Kiselev E.G.) 


\title{
Тепловые и механические свойства биокомпозита
}

\section{на основе поли-3-гидроксибутирата и бионаполнителя}

\author{
Е.Г. Киселев ${ }^{\text {a }}$, А.П. Кузьмин ${ }^{\text {a }}$, И.В. Немцев ${ }^{\sigma}$ \\ ${ }^{a}$ Сибирский федеральный университет \\ Россия, 660041, Красноярск, пр. Свободный, 79 \\ ${ }^{\sigma} Ф И Ц$ «Красноярский научный центр СО РАН» \\ Россия, 660036, Красноярск, Академгородок, 43/50
}

Биоразлагаемыій поли-3-гидроксибутират [P(3НВ)] и березовые опилки (в качестве наполнителя) использованы для приготовления порошкообразных смесей с целью получения форм в виде гранул и таблеток. Таблетки получены прямым холодным прессованием порошков полимера и наполнителя, гранулы - техникой гранулирования из пасты смеси полимера с опилками, увлажненной этанолом. Свойства исходного полимера, наполнителя и полученных смесей изучень с помощью ИК-спектроскопии, дифференциальной сканирующей калориметрии, рентгенографии и электронной микроскопии. Химических связей между компонентами обнаружено не было, следовательно, эти смеси представляют собой физические смеси. Степень кристалличности смесей была ниже, чем уисходного полимера, что свидетельствует о различной кинетике кристаллизации смесей. Увеличение содержания наполнителя в полимере снижало механическую прочность. Полученный на основе биоразлагаемого полимера и опилок композит имеет перспективу в качестве нетоксичного материала для производства древесных плит для стройиндустрии и мебельной промышленности вместо материалов, изготовленных с использованием токсичных полиэфирных смол.

Ключевые слова: $Р(3 Н B)$, древесные опилки, филлер, полимерные смеси, физико-химические и механические свойства.

\section{Introduction}

The concept of sustainable development is one of the basic ideas of the $21^{\text {st }}$ century. New methods of economic management should decrease the rates of consumption of nonrenewable fossil resources, preserve them for future generations, enable more effective use of energy resources, and introduce new, functional, and environmentally friendly recyclable materials in industrial production. The annual production of synthetic plastics has exceeded 350 million tons, and they largely accumulate in landfills, occupying fertile, arable lands. Plastic wastes ruin municipal sewage and drainage systems. Industrial ecology and green chemistry are tools for creating new ecofriendly materials, including those manufactured from renewable sources (Qaiss et al., 2015). Hybrids based on synthetic polyolefins and natural materials have been increasingly used in various applications. Polymers synthesized by living systems, so-called biopolymers, have also attracted considerable attention. Among various natural materials, a special place is occupied by polyhydroxyalkanoates (PHAs) - microbial polymers that can be used in different areas, primarily in medicine. PHAs are degraded to harmless products $\left(\mathrm{CO}_{2}\right.$ and $\mathrm{H}_{2} \mathrm{O}$ ); they are biocompatible, mechanically 
strong, thermoplastic, capable of blending with other materials, and processable by conventional methods from different phase states.

However, high costs hinder the use of PHAs in technical applications such as agriculture (films and pots for greenhouses, carriers for fertilizers and agrochemicals); production of packages, containers, and household goods; and use in the construction industry, which require very large amounts of material. A possible approach is to use PHA blends with cheaper materials, which can both reduce the cost of the material and modify the properties of the polymers. Wood flour, as well as other wood waste, is produced in great quantities everywhere, and thus is a potentially useful material for manufacturing hybrids. A literature search revealed few studies that describe the results of using natural materials, including waste, as fillers. Angelini et al. (2016) reported using a lignocellulosic biomass (LC), biowaste from a second-generation bioethanol production process, as a filler of $\mathrm{P}(3 \mathrm{HB})$. Other studies (Khunthongkaew et al., 2018; Iewkittayakorn et al., 2017) discuss properties and potential uses of wood waste and PHA to fabricate wood particle boards. These studies proved that PHAs could serve as nontoxic binding materials instead of toxic formaldehyde resins. The water resistance of the material also increased when made into a blend: water absorption decreased from 115.48 to $85.62 \%$. The authors concluded that such mixes were promising materials for the construction industry. A similar conclusion was reached in another study (Bascaran et al., 2012), in which PHAs were tested as adhesive materials, and particleboards made from oil palm trunks with the addition of PHA were stronger than boards fabricated without adding PHA. Studies by Bin Bakri et al. (2018, 2018a) describe using acacia wood and discuss the positive eco-economic aspect of using wood waste in combination with degradable polymers such as PHAs.
The purpose of this study was to produce $\mathrm{P}(3 \mathrm{HB})$ biocomposites using wood flour as a biofiller and to study their thermal, mechanical, and morphological properties.

\section{Materials and methods}

Samples of $\mathrm{P}(3 \mathrm{HB})$ were synthesized by using the Cupriavidus eutrophus B10646 wildtype strain at the Institute of Biophysics SB RAS. Polymers were extracted from cells with chloroform, and the extracts were precipitated using hexane. The composition of the polymers was analyzed with a gas chromatography-mass spectrometry device (6890/5975C, Agilent Technologies, U.S.). Wood flour was produced by grinding birch wood (Betula pendula Roth) using an MD 250-85 woodworking machine ("StankoPremyer", Russia). The polymer and filler were pulverized by impact and shearing action in an ultracentrifugal mill ZM 200 (Retsch, Germany). To achieve high fineness of polymer grinding, the material and the mill housing with the grinding tools were preliminarily cooled at $-80^{\circ} \mathrm{C}$ for approximately $30 \mathrm{~min}$ in an Innova U101 freezer (New Brunswick Scientific, U.S.). The fractioning time was $10 \mathrm{~min}$, amplitude $1.5 \mathrm{~mm}$, and a $100 \mathrm{~g}$ sample was used. Fractions of the polymer and filler powders of $200 \mu \mathrm{m}$ and less were selected and used. Then, polymer powder was mixed with filler powder in a SpeedMixer DAC 250 SP benchtop planetary mixer (Hauschild Eng., Germany); the blend time was $1 \mathrm{~min}$, and the speed was $1000 \mathrm{rpm}$. The homogenized blends were used to produce pellets and granules. Pellets were prepared by cold pressing at 36 bar using a laboratory semiautomatic press (Minipress, Minsk, Belarus). Granules were prepared by mixing wet polymer paste $(40 \%)$ in ethanol in the planetary mixer SpeedMixer DAC 250 SP.

Poly-3-hydroxybutyrate, wood powders, powdered $\mathrm{P}(3 \mathrm{HB}) /$ filler blend, and granules and pellets were examined by using state-of- 
the-art physicochemical methods. The surface microstructure of the pellets and granules prepared from the blends was analyzed using scanning electron microscopy (a TM-3000 Hitachi microscope with the QUANTAX 70 program, Japan). All initial materials and blends were analyzed using FTIR spectroscopy. IR spectra were taken in the 400-4000 $\mathrm{cm}^{-1}$ range using a "NICOLET 6700" FT-IR spectrometer (Thermo Scientific, U.S.) and a Smart Orbit accessory with the attenuated total reflection (ATR) technique. Thermal analysis of the initial materials and blends was performed using a DSC-1 differential scanning calorimeter (METTLER TOLEDO, Switzerland). X-ray structure analysis and determination of the crystallinity of the initial materials and blends were performed employing a D8 ADVANCE X-ray powder diffractometer equipped with a VANTEC fast linear detector using $\mathrm{CuKa}$ radiation (Bruker, AXS, Germany). The mechanical properties of the pellets and granules were investigated using an Instron 5565 electromechanical tensile testing machine (U.K.).

Statistical analysis of the results was performed by conventional methods using the standard software package of Microsoft Excel. Arithmetic means and standard deviations were found. The statistical significance of the results was determined using Student's $t$-test(significance level: $\mathrm{P} \leq 0.05$ ). Statistical analysis of the surface properties of the samples was performed by using embedded methods from the DSA-4 software.

\section{Results and discussion}

Poly-3-hydroxybutyrate and birch wood flour with considerably different properties (Table 1) were used to produce $\mathrm{P}(3 \mathrm{HB}) /$ filler blends. $\mathrm{P}(3 \mathrm{HB})$ is a highly crystalline material with a prevailing crystalline phase, and its degree of crystallinity $\left(\mathrm{C}_{\mathrm{x}}\right)$ is usually above $60-65 \%$; the $\mathrm{C}_{\mathrm{x}}$ of the $\mathrm{P}(3 \mathrm{HB})$ sample used in this study was $75 \%$. Diffraction peaks in $2 \Theta=13.4,16.8$, 20, 22.2 and $25.5^{\circ}$ had similar patterns when compared with previous crystallographic data for this material (Laycock et al., 2013). X-ray diffraction patterns of the filler differed from the diffraction pattern of $\mathrm{P}(3 \mathrm{HB})$. Wood flour showed distinct diffraction peaks at $2 \Theta=14.2$, 19.6 , and $25.5^{\circ}$. The thermal properties of the polymer and filler were also different. $\mathrm{P}(3 \mathrm{HB})$ is a thermoplastic material with a considerable difference between the melting point $\left(176^{\circ} \mathrm{C}\right)$ and thermal decomposition temperature $\left(287^{\circ} \mathrm{C}\right)$. The $\mathrm{P}(3 \mathrm{HB})$ crystallization temperature is $108^{\circ} \mathrm{C}$, and the melting enthalpy is $89.3 \mathrm{~J} / \mathrm{g}$. By contrast, the filler is not a thermoplastic material. The initial heating of these materials (and blends) gave a

Table 1. Physicochemical properties of initial materials and blends

\begin{tabular}{|c|c|c|c|c|c|}
\hline Sample & $\mathrm{C}_{\mathrm{x}}, \%$ & $\mathrm{~T}_{\text {melt., }}{ }^{\circ} \mathrm{C}$ & $\mathrm{T}_{\text {cryst. }}{ }^{\circ} \mathrm{C}$ & $\mathrm{T}_{\text {degr. }}{ }^{\circ} \mathrm{C}$ & $\begin{array}{c}\text { Melting } \\
\text { enthalpy, (J/g) }\end{array}$ \\
\hline \multicolumn{7}{|c|}{ Initial materials } \\
\hline $\mathrm{P}(3 \mathrm{HB})$ & 75 & 176 & 108 & 287 & 89.3 \\
\hline wood flour & 26 & - & - & $220 *$ & 66.9 \\
\hline \multicolumn{7}{|c|}{$\mathrm{P}(3 \mathrm{HB}) /$ wood flour blends } \\
\hline $90 / 10$ & 65 & 178 & 107 & 279 & 51.3 \\
\hline $70 / 30$ & 47 & 175 & 106 & 273 & 45.4 \\
\hline $50 / 50$ & 44 & 171 & 104 & 274 & \\
\hline
\end{tabular}

$(*)$ - start of $\mathrm{T}_{\text {degr. }}$. 

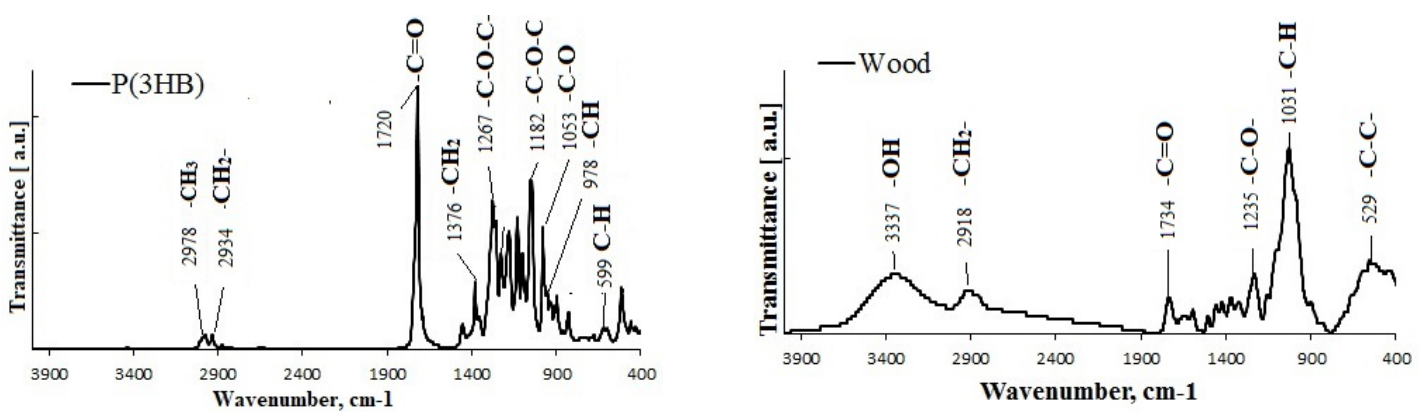

Fig. 1. FT-IR spectra of $\mathrm{P}(3 \mathrm{HB})$ and wood flour

small peak at a temperature between 70 and $130^{\circ} \mathrm{C}$, which was associated with the evaporation of moisture and volatile organic compounds.

Possible structural differences between poly3-hydroxybutyrate, wood flour, and powdered $\mathrm{P}(3 \mathrm{HB}) /$ filler blend were detected using IR spectroscopy, which is employed to study the structures of various macromolecules. Variations in the intensity of the bands in the low-frequency range are indicators of both the crystalline-toamorphous phase ratio in the blend and the type of interactions of the components in the blend.

FT-IR spectra of $\mathrm{P}(3 \mathrm{HB})$ and the filler were taken in the $400-4000 \mathrm{~cm}^{-1}$ range (Fig. 1). The spectra showed not only the groups of carbon compounds $\left(\mathrm{C}=\mathrm{O}, \mathrm{C}-\mathrm{OH}, \mathrm{CH}_{2}, \mathrm{CH}_{3}\right)$ contained in both initial materials but also the groups and compounds characteristic of the individual components. Those consisted of $\mathrm{CH}, \mathrm{CH}_{2}, \mathrm{CH}_{3}$, $\mathrm{C}-\mathrm{OH}$, and $\mathrm{COOH}$ groups for $\mathrm{P}(3 \mathrm{HB})$ and $-\mathrm{C}-\mathrm{O}-$; -C-O-C- for birch wood flour.

The IR absorption spectra of $\mathrm{P}(3 \mathrm{HB}$ ) (Fig. 1) contained absorption bands corresponding to vibrations of the main structural components of the polymers except for the absorption bands of vibrations of the terminal $\mathrm{C}-\mathrm{OH}$ and $\mathrm{COOH}$ groups. The bands of the ordered optical densities (crystalline phase) were in the $1228 \mathrm{~cm}^{-1}$ range, while the bands of the amorphous phase were shifted to $1182 \mathrm{~cm}^{-1}$. The spectra showed distinct absorption bands of asymmetric stretching of the $\mathrm{CH}_{3}$ - and $\mathrm{CH}_{2}$ - groups (2978 and $2994 \mathrm{~cm}^{-1}$ ); symmetric stretching of the $\mathrm{CH}$ - and $\mathrm{CH}_{2}$ groups (2994 and $2934 \mathrm{~cm}^{-1}$ ); stretching of conjugated $\left(1687 \mathrm{~cm}^{-1}\right)$ and unconjugated $\left(1720 \mathrm{~cm}^{-1}\right)$ carbonyl groups $\mathrm{C}=\mathrm{O}$; skeletal $\mathrm{CH}$ vibrations (599 $\left.\mathrm{cm}^{-1}\right)$; and $\mathrm{CH}$ bending $\left(622 \mathrm{~cm}^{-1}\right)$. PHAs are hydrophobic compounds in which molecules of water interact with the hydrogen atom of the methyl group or with the oxygen atom of the carboxyl group through hydrogen bonding. The narrow bands at $3436 \mathrm{~cm}^{-1}$ were typical of the hydrogen-bonded $\mathrm{OH}$ group. The $1687 \mathrm{~cm}^{-1}$ band was characteristic of hydrogen vibrations in the $\mathrm{OH}$ group interacting with the oxygen atom through hydrogen bonding. The 2874, 2934, 2978, and $2994 \mathrm{~cm}^{-1}$ absorption bands were typical of the bonded $\mathrm{OH}$ group and may be a component of the $\mathrm{COOH}$ dimer group. In the $3000-2500 \mathrm{~cm}^{-1}$ range, there was a group of weak bands typical of the dimers of carboxylic acids.

IR spectra of the birch wood flour (Fig. 1) showed plane bending of the guaiacyl ring of lignin of leaves $\left(1031 \mathrm{~cm}^{-1}\right)$, stretching of -C-O-; -C-O-C- $\left(1235 \mathrm{~cm}^{-1}\right)$, skeletal vibrations of the syringyl ring of the lignin found in leaves (1324 $\mathrm{cm}^{-1}$ ), stretching and skeletal vibrations of the benzene ring $\left(1422 \mathrm{~cm}^{-1}, 1504 \mathrm{~cm}^{-1}\right.$, $\left.1593 \mathrm{~cm}^{-1}\right)$, stretching of $-\mathrm{C}=\mathrm{O}$ of conjugated and unconjugated groups $\left(1652 \mathrm{~cm}^{-1}, 1734 \mathrm{~cm}^{-1}\right)$, and intramolecular and intermolecular stretching of $-\mathrm{OH}$ groups and water $\left(3337-3342 \mathrm{~cm}^{-1}\right)$. 
Elemental analysis of the samples was performed using a scanning electron microscope equipped with a system for X-ray spectrometry (Table 2). The initial $\mathrm{P}(3 \mathrm{HB})$ contained only carbon (66.96 at.\%) and oxygen (33.04 at.\%). The $\mathrm{P}(3 \mathrm{HB}) /$ wood flour blend also contained silicon, aluminum, iron, calcium, and sulfur.

Powdered $\mathrm{P}(3 \mathrm{HB})$ and filler were processed by cold pressing to produce pellets with a diameter of $6 \mathrm{~mm}$ and height $3 \mathrm{~mm}$ and granules with a diameter of $2 \mathrm{~mm}$ and length of between 2 and $4 \mathrm{~mm}$.
Pellets and granules prepared from blends of $\mathrm{P}(3 \mathrm{HB})$ with filler, which had different properties, exhibited diverse surface structures (Fig. 2). SEM images showed porous and rough surface microstructures. The surface of the $\mathrm{P}(3 \mathrm{HB}) /$ wood flour pellets showed rectangular wood flour particles embedded in the surface layer.

The blends were characterized using DSC, $\mathrm{X}$-ray examination, and IR spectroscopy. The IR spectra of the blend are shown in Fig. 3.

IR spectrometry showed that characteristic absorption bands of the initial components were separately retained in all blends: for $\mathrm{P}(3 \mathrm{HB})$,

Table 2. Elemental composition of $\mathrm{P}(3 \mathrm{HB})$ and blend $(\mathrm{P}(3 \mathrm{HB}) /$ filler $=70 / 30)$ samples (atomic \%)

\begin{tabular}{|c|c|c|}
\hline Element & $\mathrm{P}(3 \mathrm{HB})$ & $\mathrm{P}(3 \mathrm{HB}) /$ wood flour \\
\hline $\mathrm{C}$ & $66.96 \pm 6.5$ & $67.03 \pm 6.4$ \\
\hline $\mathrm{O}$ & $33.04 \pm 4.5$ & $32.03 \pm 4.2$ \\
\hline $\mathrm{Si}$ & - & 0.26 \\
\hline $\mathrm{Al}$ & - & 0.13 \\
\hline $\mathrm{Fe}$ & - & $0.22 \pm 0.1$ \\
\hline $\mathrm{Mg}$ & - & - \\
\hline $\mathrm{K}$ & - & 0.26 \\
\hline $\mathrm{Ca}$ & - & - \\
\hline $\mathrm{Na}$ & - & - \\
\hline $\mathrm{Ti}$ & - & - \\
\hline $\mathrm{Mn}$ & - & 0.08 \\
\hline $\mathrm{S}$ & - & \\
\hline
\end{tabular}

$(-)$ not detected.
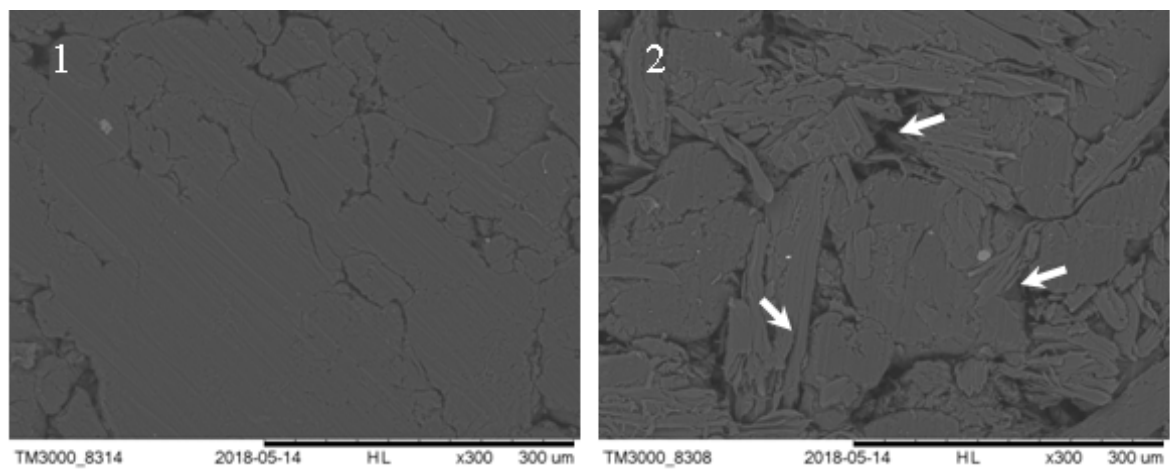

Fig. 2. SEM images of pressed pellets: 1 - $\mathrm{P}(3 \mathrm{HB}) ; 2-\mathrm{P}(3 \mathrm{HB}) /$ wood flour (70/30 blend)

$$
-307-
$$




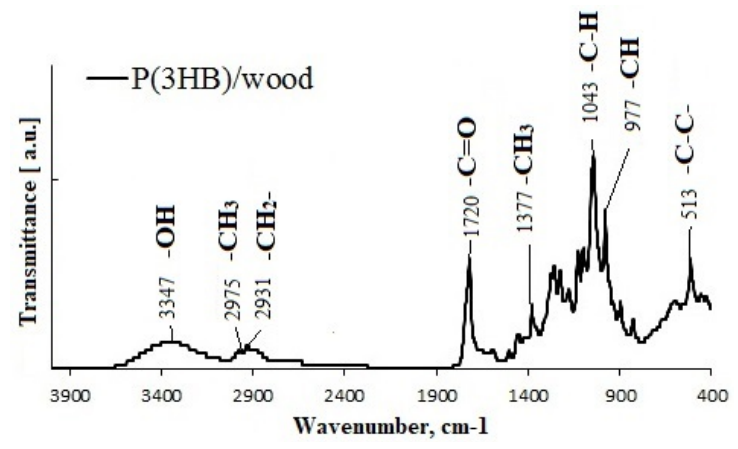

Fig. 3. FT-IR spectra of the 70/30 P(3HB)/wood flour blend

those were the $\mathrm{CH}, \mathrm{CH}_{2}, \mathrm{CH}_{3}, \mathrm{C}-\mathrm{OH}$, and $\mathrm{COOH}$ groups; for birch wood flour, it was the -C-O-; -C-O-C- group. In the spectra of the blend, absorption bands were either separate bands or coinciding peaks, some of them transformed. An insignificant difference in numbers was within the limits of spectral error $-4 \mathrm{~cm}^{-1}$ (accumulation of 256 scans) - and could result from the increased moisture content of some of the samples. No new significant absorption bands were revealed in the blends, suggesting that no new chemical bonds were formed and that the blends prepared by the techniques employed in this study were physical mixtures.

Blending of $\mathrm{P}(3 \mathrm{HB})$ with the filler changed the properties of the polymer. The blends became progressively amorphous as the percentage of the filler was increased $(10,30$, and 50\% fillings of the polymer with natural materials were tested). The degree of crystallinity of $\mathrm{P}(3 \mathrm{HB})$ decreased noticeably in the blends with wood flour (a material with low $\mathrm{C}_{\mathrm{x}}$ ). The $\mathrm{C}_{\mathrm{x}}$ of the $\mathrm{P}(3 \mathrm{HB}) /$ wood flour blends with $30 \%$ filler decreased to $47 \%$; the $\mathrm{C}_{\mathrm{x}}$ of the blends with $50 \%$ of the same filler decreased to $44 \%$. That is, the amorphous phase prevailed in those blends. Changes in the crystallization kinetics of the polymer in the blend were associated with the rather high percentages of fillers (30 and 50\%). This must have decreased the free volume necessary for nucleation of spherulites to occur, preventing the development of the crystalline phase and thus reducing its prevalence.

Thermograms of the blends were taken over a wide range of temperatures, including the boundaries of melting and thermal decomposition. Our results showed that the filler did not significantly affect the temperatures of melting and thermal decomposition of $\mathrm{P}(3 \mathrm{HB})$ but considerably decreased the enthalpy of melting (Table 1). Compared to the enthalpy of melting of $\mathrm{P}(3 \mathrm{HB})(89.3 \mathrm{~J} / \mathrm{g})$, the enthalpy of melting of the blends containing $30 \%$ wood flour decreased to $51.3 \mathrm{~J} / \mathrm{g}$ and to $45.4^{\circ} \mathrm{C}$ for the blends with $50 \%$ filler. The melting temperature was not affected by the filler, as it is largely the property of the polymer matrix. The components of the blend (polymer and filler) were mixed mechanically, the chemical structure of the polymer remained unchanged, and thus, the filler did not produce any effect on the melting temperature. For the $\mathrm{P}(3 \mathrm{HB}) /$ wood flour blend $(70 / 30)$, the degradation peak was observed at $273^{\circ} \mathrm{C}$ (at a temperature $14^{\circ} \mathrm{C}$ lower than the temperature for the pure polymer), and the onset of decomposition occurred at $259^{\circ} \mathrm{C}$. A possible reason for the lower temperatures for the decomposition of the $\mathrm{P}(3 \mathrm{HB}) /$ wood flour blend could be the accumulation of wood flour decomposition products in the melt, which could catalyze destruction of the polymer matrix; for 
the $\mathrm{P}(3 \mathrm{HB}) /$ wood flour blend, the temperature of crystallization was insignificantly lower. Wood flour particles could serve as defect centers and prevent polymer chains from folding, producing smaller crystals and causing the temperature of crystallization to decrease. In the conditions of the thermal analysis, the glass transition temperature was not registered.

Based on the analysis of the results obtained, the following model of the composite was proposed (Fig. 4).

Analysis of the physical/mechanical properties of the pellets prepared from the initial materials and blends is shown in Fig. 5 (granules had very low values and, therefore, they were not examined).

Young's moduli of the pellets prepared from initial materials varied considerably, and the highest value was obtained for $\mathrm{P}(3 \mathrm{HB})$ pellets (350 MPa). Young's moduli of the filler were lower: $289 \mathrm{MPa}$ for the wood flour pellets. Under downward force applied to the pellets prepared from the blends, the compressive strength of the pellets consistently decreased as the percentage of the filler increased. $\mathrm{P}(3 \mathrm{HB}) /$ wood flour pellets showed high resistance: Young's moduli of the pellets with $30 \%$ and $50 \%$ of the filler reached 310 and $276 \mathrm{MPa}$, respectively. The reason for this could be the amorphization of the blends: the amount of the polymer, in which the crystalline phase prevailed (75\%), decreased and the amount of the filler, with the prevailing amorphous phase, increased.

\section{Conclusions}

Natural material-birch wood flour-was used as filler for degradable poly-3-hydroxybutyrate. Analysis of IR spectra showed that no chemical bonds were established between the polymer and filler and that the blends were physical
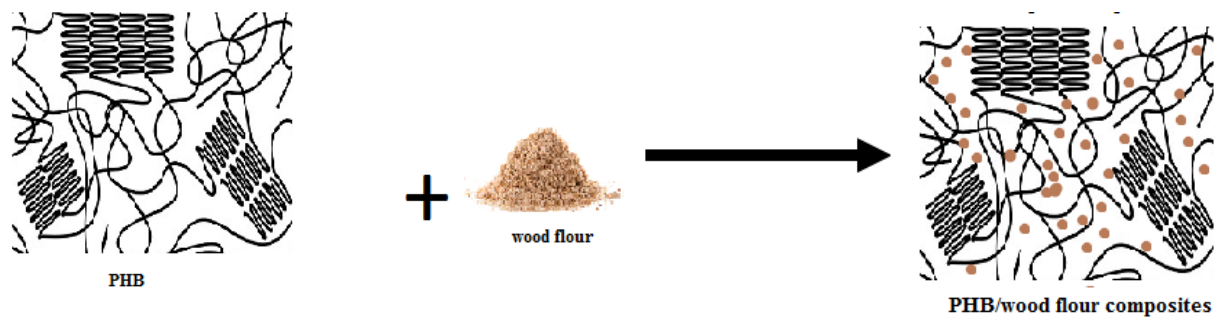

Fig. 4. Schematic representation of the original polymer, wood flour, and $\mathrm{P}(3 \mathrm{HB})$ /wood flour composites

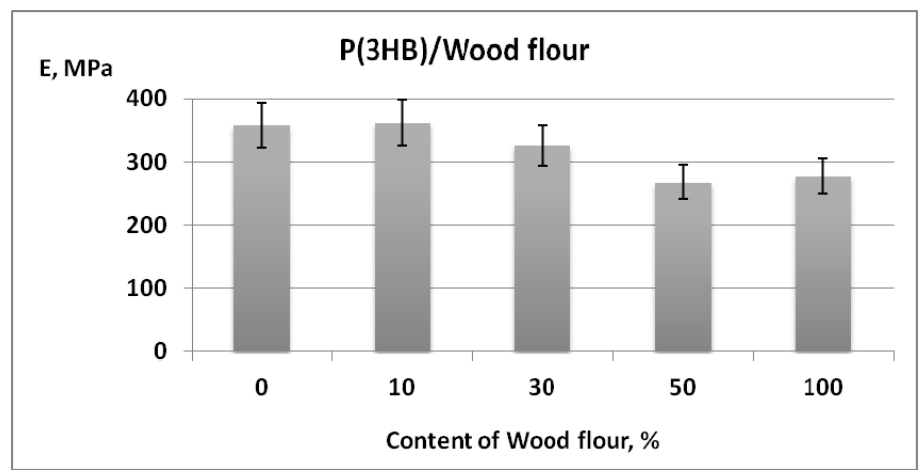

Fig. 5. Young's modulus of the pressed pellets prepared from blends of $\mathrm{P}(3 \mathrm{HB})$ and wood flour mixed in different proportions 
mixtures. Their temperature characteristics and degrees of crystallinity were lower than those of $\mathrm{P}(3 \mathrm{HB})$ alone, suggesting different crystallization kinetics of the blends. The hydrophobic $\mathrm{P}(3 \mathrm{HB})$, mixed with natural material, acquired the ability to sorb moisture; Young's modulus of the blends was lower than that of $\mathrm{P}(3 \mathrm{HB})$. The resulting composite, based on biodegradable polymers and wood flour, is a promising nontoxic material for the production of wood-based panels for the construction industry and the manufacture of furniture in place of materials produced using toxic polyester resins.

\section{Acknowledgements}

The study was performed using equipment from the Shared Instrument Facility of Federal Research Center "Krasnoyarsk Science Center SB RAS", 43/50 Akademgorodok, Krasnoyarsk, 660036, Russia.

\section{References}

Angelini S., Cerruti P., Immirzi B., Scarinzi G., Malinconico M. (2016) Acid-insoluble lignin and holocellulose from a lignocellulosic biowaste: bio-fillers in poly(3-hydroxybutyrate). European Polymer Journal, 76: 63-76

Baskaran M., Hashim R., Said N., Raffi S.M., Balakrishnan K., Sudesh K., Sulaiman O., Arai T., Kosugi A., Mori Y., Sugimoto T., Sato M. (2012) Properties of binderless particleboard from oil palm trunk with addition of polyhydroxyalkanoates. Composites Part B: Engineering, 43(3): 1109-1116

Bin Bakri M.K., Jayamani E., Hamdan S., Rahman M.R., Kakar A. (2018) Potential of Borneo Acacia wood in fully biodegradable bio-composites' commercial production and application. Polymer Bulletin, 75(11): 5333-5354

Bin Bakri M.K., Jayamani E., Heng S.K., Kakar A. (2018a) Short review: potential production of Acacia wood and its biocomposites. Materials Science Forum, 917: 37-41

Iewkittayakorn J., Khunthongkaew P., Chotigeat W., Sudesh K. (2017) Effect of microwave pretreatment on the properties of particleboard made from para rubber wood sawdust with the addition of polyhydroxyalkanoates. Sains Malaysiana, 46(9): 1361-1367

Khunthongkaew P., Murugan P., Sudesh K., Iewkittayakorn J. (2018) Biosynthesis of polyhydroxyalkanoates using Cupriavidus necator $\mathrm{H} 16$ and its application for particleboard production. Journal of Polymer Research, 25: 131

Laycock B., Halley P., Pratt S., Werker A., Lant P. (2013) The chemomechanical properties of microbial polyhydroxyalkanoate. Progress in Polymer Science, 38(3-4): 536-583

Qaiss A., Bouhfid R., Essabir H. (2015) Characterization and use of coir, almond, apricot, argan, shell, and wood as reinforcement in the polymeric matrix in order to valorize these products. Agricultural biomass based potential materials. Hakeem K., Jawaid M., Y. Alothman O. (eds.) Springer, Cham, p. 305-339 